\title{
Article \\ Cone-Bearing Branches of Pinus koraiensis Are Not Carbon Autonomous during Cone Development
}

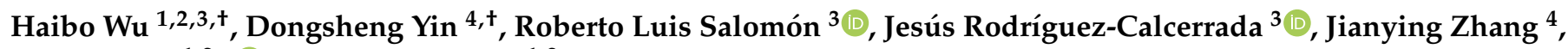 \\ Peng Zhang 1,2,*iD and Hailong Shen ${ }^{1,2}$ \\ 1 State Key Laboratory of Tree Genetics and Breeding, School of Forestry, Northeast Forestry University, Harbin \\ 150040, China; WHB152407@163.com (H.W.); shenhl-cf@nefu.edu.cn (H.S.) \\ 2 State Forestry and Grassland Administration Engineering Technology Research Center of Korean Pine, \\ Harbin 150040, China \\ 3 Department of Natural Systems and Resources, Universidad Politécnica de Madrid, Ciudad Universitaria \\ s/n, 28040 Madrid, Spain; roberto.salomon@upm.es (R.L.S.); jesus.rcalcerrada@upm.es (J.R.-C.) \\ 4 Forestry Research Institute of Heilongjiang Province, Harbin 150081, China; \\ yindongsheng2004@126.com (D.Y.); zhangjianying1124@126.com (J.Z.) \\ * Correspondence: zhangpeng@nefu.edu.cn \\ + These authors contributed equally to this work.
}

check for updates

Citation: Wu, H.; Yin, D.; Salomón, R.L.; Rodríguez-Calcerrada, J.; Zhang, J.; Zhang, P.; Shen, H. Cone-Bearing Branches of Pinus koraiensis Are Not Carbon Autonomous during Cone Development. Forests 2021, 12, 1257 https://doi.org/10.3390/f12091257

Academic Editor: Chikako Honda

Received: 3 August 2021

Accepted: 14 September 2021

Published: 16 September 2021

Publisher's Note: MDPI stays neutral with regard to jurisdictional claims in published maps and institutional affiliations.

Copyright: (c) 2021 by the authors. Licensee MDPI, Basel, Switzerland. This article is an open access article distributed under the terms and conditions of the Creative Commons Attribution (CC BY) license (https:// creativecommons.org/licenses/by/ $4.0 /)$.

\begin{abstract}
Cone development in conifer species is crucial to ensure sexual regeneration. A better understanding of carbon $(\mathrm{C})$ source-sink relations at the branch level can guide strategies for improving resource allocation to reproduction. In particular, the evaluation of $C$ relations between vegetative and reproductive branches is helpful to test whether tree branches are carbon autonomous. With this aim, we integrated girdling and defoliation treatments with ${ }^{13} \mathrm{C}$ pulse labeling in situ to evaluate $\mathrm{C}$ autonomy in cone-bearing branches of P. koraiensis during the growing season. Girdling significantly reduced branch volumetric development, branch biomass, and non-structural carbohydrates across foliar, twig, and cone tissues; it also arrested cone development. Defoliation effects on these variables were minor, although they tended to increase with defoliation intensity. In addition, ${ }^{13} \mathrm{C}$ increased by $4.5 \%$ and $45.4 \%$ after $4 \mathrm{~h}$ and $24 \mathrm{~h}$ of ${ }^{13} \mathrm{C}$ labeling in unlabeled cone-bearing branches, respectively, indicating the $\mathrm{C}$ translocation from labeled vegetative branches. These results indicate that the cone-bearing branches are not $C$ autonomous and that the development of female cones relies to a great extent on $\mathrm{C}$ import from neighboring branches. However, the amount of $\mathrm{C}$ translocated was largely dependent on manipulative alterations of the source-sink balance, thereby denoting extensive plasticity in the degree of branch $C$ autonomy. These results shed light on the reproductive physiology of P. koraiensis.
\end{abstract}

Keywords: girdling; defoliation; carbon branch autonomy; carbon reserves; carbon allocation; cone maturation; isotope labeling; Korean pine

\section{Introduction}

Carbon (C) and mineral nutrients assimilated into leaves are subject to a complex regulation to coordinate plant growth, reproduction, storage, defense, and maintenance of metabolic processes [1,2]. Roots import photoassimilates via phloem, which is mostly sucrose down a concentration gradient from the leaves [3]. Above the ground, flowers, fruits, buds, and young leaves and branches have non-negligible rates of photosynthesis that are insufficient to achieve their full development, so they import photoassimilates from neighboring adult leaves $[4,5]$. The distance between and activity of source and sink organs are the main determinants of phloem transport direction and intensity [6,7]. Thus, the $C$ autonomy of developing organs is strongly related to their sink strength and connection with neighboring $C$ sources.

Tree crowns can be considered as fully integrated modular systems made up of branches that are autonomous in assimilation, allocation, and utilization of $\mathrm{C}$ and min- 
eral nutrients [7-9]. The theory of branch autonomy has long received attention in tree physiological studies $[8,10,11]$. In support of this theory, some studies have reported that branches are fully autonomous and do not need to import photoassimilates from other organs $[8,12]$. On the contrary, the $\mathrm{C}$ consumed during branch growth or reproduction can exceed the supply of recent photoassimilates and carbohydrates stored in woody tissues of the branch. Thus, some studies have shown that photoassimilates are transported from adjacent vegetative branches to reproductive branches $[13,14]$. The disparity of results on C autonomy is likely related to the sink strength of target branches, which in turn is primarily related to branch age, canopy position, and fruit bearing load [15-17]. In line with this, the resource accumulation hypothesis [18] states that plant tissues need to store $C$ in order to support massive fruit production in masting species.

The evaluation of $C$ relations between vegetative and reproductive branches has helped to illustrate branch $\mathrm{C}$ autonomy and, more broadly, source-sink relationships and tree physiology. Manipulative experiments on manageable branches and small trees have applied girdling [19,20], defoliation and pruning [21-23] to shed light on the topic. Defoliation has variable impacts on $\mathrm{C}$ allocation to growth, storage or defense depending on the extent of defoliation, compensatory photosynthesis in remaining leaves, and downregulation of $C$ sinks in different parts of the tree. For example, a reduction in stem secondary growth can sometimes compensate for low $\mathrm{C}$ gain caused by defoliation and result in similar branch non-structural carbohydrate concentrations in defoliated and non-defoliated trees [23,24]. Meanwhile, an increase in photosynthesis per unit leaf area can compensate for partial defoliation and result in similar growth in partially defoliated and non-defoliated trees $[25,26]$. The practice of girdling has been amply applied to orchard trees to increase fruit set $[20,27,28]$. Assuming reproductive branches are $C$ autonomous, their girdling aims at stopping the export of phloem-transported sugars to vegetative organs and increasing fruit size and sugar concentration. Compared to studies exploring separate effects of defoliation and girdling on $C$ relations in reproductive branches, few studies have explored the combined effects of both treatments [8,12,29].

Carbon isotope labeling has also been widely applied to study the fate of photoassimilates within the tree. The use of ${ }^{13} \mathrm{C}$ is less costly, safer, and more convenient for signal detection than that of the radioisotope ${ }^{14} \mathrm{C}$. The transfer of ${ }^{13} \mathrm{C}$-photoassimilates has been extensively studied in grassland plants [30], tree saplings [31,32], and adult trees [33-35] mostly orchard trees [36,37]. Whole-tree labeling allowed Sha et al. [38] to study fruit sink activity across the growing season; authors found higher ${ }^{13} \mathrm{C}$-photoassimilate transfer to fruit 120 to 135 days after flowering. Branch labeling provided contrasting results in terms of $C$ autonomy in reproductive branches, from mostly autonomous in Prunus persica [36] to mostly dependent in Pyrus pyrifolia [37]. There are few reports of in situ labeling on forest tree species under natural conditions $[33,34,39]$.

Branch C autonomy has been mostly investigated on orchard plants $[9,20,27,29,36-38]$ due to their economic importance, in broadleaf species $[8,10,12,14,34]$, and, to the best of our knowledge, only a few studies have been performed in conifer species [40,41]. Pinus koraiensis Siebold \& Zucc. (Korean pine) is one of the most important native tree species in northeastern China; it thrives naturally between North Korea in the north and far east Russia in the south [42]. P. koraiensis has been extensively used as a major source of timber and edible pine nuts because of the excellent properties of its wood and the nutritional value of the pine nuts [43]. P. koraiensis is one of the major nut trees in the world, but its cultivation remains at an early stage of domestication compared to other similar orchard trees (e.g., almond or walnut). Thus, nut production is still based on wild genotypes. One of the greatest management issues in nut production is the masting behavior of the species. High costs of reproduction during masting years can induce trade-offs in resource allocation to other functions, such as growth, defense, and reproduction, in the following years. Because plants are modular organisms, strategies for improving resource allocation to reproduction can benefit from studies on $\mathrm{C}$ source-sink relationships at the branch level. 
Here, we examined the $\mathrm{C}$ autonomy of reproductive branches of $P$. koraiensis by means of two manipulative experiments. In Experiment 1, girdling and defoliation of cone-bearing (i.e., reproductive) branches were applied in a factorial manner. In Experiment $2,{ }^{13} \mathrm{C}$ labeling was applied to vegetative branches to track the movement of ${ }^{13} \mathrm{C}$-photoassimilates to adjacent reproductive branches, with the main branch supporting both the vegetative and reproductive branches being either girdled or ungirdled. The main objective is to discover whether growth, concentration of non-structural carbohydrates, and reproductive output (e.g., cone number, cone biomass, and seed content) of reproductive branches are dependent on carbohydrates assimilated in neighboring vegetative branches. We hypothesized that if branches were $\mathrm{C}$ autonomous, defoliation of reproductive branches would have a major effect on their performance, due to the lack of local photoassimilates, and girdling a minor effect. Alternatively, if branches were not $C$ autonomous, defoliation would have a minor effect and girdling a major effect, due to the arrested import of nonstructural carbohydrates to reproductive branches. Moreover, under the hypothesis of $C$ autonomy, ${ }^{13} \mathrm{C}$ infused to vegetative branches would not move to reproductive branches independently of girdling of the main supporting branch.

\section{Materials and Methods}

\subsection{Study Site and Sampled Trees}

The study site is located at the Maoershan Research Station of the Northeast Forestry University $\left(127^{\circ} 30^{\prime}-127^{\circ} 34^{\prime} \mathrm{E}, 45^{\circ} 21^{\prime}-45^{\circ} 25^{\prime} \mathrm{N}\right.$; Heilongjiang, China). The area belongs to the northwest ridge of the Zhangguangcai Mountains and is characterized by a continental temperate monsoon climate, with warm humid summers and cold dry winters. The average annual temperature is $3.1^{\circ} \mathrm{C}$, fluctuating widely between an average monthly temperature of $-19.6{ }^{\circ} \mathrm{C}$ during January and $20.9{ }^{\circ} \mathrm{C}$ during July. The growing season lasts from May to September, with an approximate duration of 120-140 days. The mean annual precipitation is $723 \mathrm{~mm}$, with $477 \mathrm{~mm}$ occurring from June to August. The study site is located $490-510 \mathrm{~m}$ above sea level, and its average slope is $15 \mathrm{o}$ north-facing. Soils are Hap-Boric Luvisols, with high organic matter content and good drainage.

Two $P$. koraiensis plantations of different age were selected to perform two parallel experiments during the 2018 growing season. One experiment consisted of the application of defoliation and girdling treatments on tree branches and was conducted in a 54-year-old plantation (hereafter referred to as Experiment 1). The second experiment consisted of isotopic labeling and was conducted in a younger 25-year-old plantation to facilitate canopy accessibility (hereafter referred to as Experiment 2). The year 2018 was a mast year, with cones being significantly higher in both plantations than in either of the previous two years. For Experiment 1, six healthy trees with a large production of cones were selected. Trees were sufficiently spaced to prevent significant shading by neighbors and were accessible for climbing. Average ( \pm standard error) tree height and diameter at breast height at the time of measurement were $13.5( \pm 0.6) \mathrm{m}$ and $34.0( \pm 3.6) \mathrm{cm}$, respectively. For Experiment 2, twelve healthy trees were selected. Crowns of selected trees did not substantially shade each other. Average ( \pm standard error) tree height and diameter at breast height at the time of measurement were $3.95( \pm 0.13) \mathrm{m}$ and $8.57( \pm 0.19) \mathrm{cm}$, respectively.

\subsection{Experiment 1}

\subsubsection{Girdling and Defoliation Treatments}

Girdling and defoliation treatments were applied to elucidate the origin of photoassimilates used for cone development and branch growth. Different treatment intensities were tested for defoliation $(0,50$, and $100 \%)$ in either girdled or ungirdled branches in a factorial manner, resulting in six treatment groups: (1) ungirdled and $0 \%$ defoliated, namely control; (2) ungirdled and 50\% defoliated; (3) ungirdled and 100\% defoliated; (4) girdled and $0 \%$ defoliated; (5) girdled and 50\% defoliated; (6) girdled and 100\% defoliated. Six cone-bearing (reproductive) branches per tree were selected from the sun-lit southwest section of the canopy and one branch per tree was randomly assigned to each treatment 
combination, thereby resulting in six treatment replicates. Average ( \pm standard error) branch length and diameter were $32.69( \pm 1.03) \mathrm{cm}$ and $16.56( \pm 0.77) \mathrm{mm}$, respectively. Girdling was performed at the base of treated branches by carefully removing a $1 \mathrm{~cm}$-wide stripe of bark, phloem, and cambium above the xylem with a razor blade. To minimize post-girdling desiccation, girdles were tightly covered with parafilm. Defoliation was performed by clipping two-year-old brachyblasts (containing 5 needles each) of the selected branches, either all brachyblasts (for $100 \%$ defoliation) or every second brachyblast (for $50 \%$ defoliation). Note that one-year-brachyblasts were not clipped, as these were not present at the time of treatment application. Treatments were simultaneously applied on day of year (DOY) 125, and treated branches were harvested on DOY 254.

Branch base diameter, branch length, and number of cones were measured or counted before treatment application. After harvest, branch base diameter and length were measured in one-year-old shoots (Y1 hereafter; see Figure S1). Additionally, twig survival rate was estimated as the percentage of twigs within the treated branch surviving from DOY 125 to DOY 254. Cone survival rate was estimated likewise. Foliar (needles), twig (xylem and phloem, including bark), and cone (including the seeds) tissues were manually separated to determine dry biomass. Tissues were immediately frozen in liquid nitrogen to stop all biochemical processes and then stored in a freezer at a temperature of $-80^{\circ} \mathrm{C}$ until lyophilization. All samples were lyophilized for $48 \mathrm{~h}$ and the dry mass was recorded for each tissue. The dried material was ground into a fine powder in a steel ball mill (Retsch MM400, German) and dry-stored for further biochemical analyses.

\subsubsection{Non-Structural Carbohydrates}

Concentration of soluble sugars and starch were determined via spectrophotometry (model UV-PC01; Shimadzu Corp., Kyoto, Japan) using a modified protocol of the phenolsulphuric acid method [44,45]. Briefly, to extract the soluble sugars, $40 \mathrm{mg}$ of dry sample were dissolved in $80 \%$ ethanol $(v / v)$ overnight; the solution was then centrifuged for $10 \mathrm{~min}$ at $3000 \mathrm{rpm}$, and the supernatant was adjusted to $50 \mathrm{~mL}$ with deionized water. Concentration of soluble sugars was determined at $490 \mathrm{~nm}$ in $1 \mathrm{~mL}$ supernatant with $1 \mathrm{~mL}$ $28 \%$ phenol solution and $5 \mathrm{~mL}$ concentrated sulphuric acid. After this, the powder was dried overnight at $40{ }^{\circ} \mathrm{C}$. Starch was extracted by hydrolysing the dried pellet at $100{ }^{\circ} \mathrm{C}$ for $3 \mathrm{~h}$ and boiling a $3 \%$ chlorhydric acid $(w / w, 0.08 \mathrm{~N})$ solution for $0.5 \mathrm{~h}$ to convert starch into soluble sugars. The extract was centrifuged for $10 \mathrm{~min}$ at $3000 \mathrm{rpm}$, then filtrated, and the supernatant adjusted to $25 \mathrm{~mL}$ with deionized water. The starch was determined in $1 \mathrm{~mL}$ supernatant with $1 \mathrm{~mL} 28 \%$ phenol and $5 \mathrm{~mL} 98 \%$ sulphuric acid $(w / w)$ at $490 \mathrm{~nm}$. The concentration of non-structural carbohydrates ([NSC]) was estimated as the sum of the soluble sugar and starch concentration. The NSC content in each organ was estimated by multiplying [NSC] by the corresponding biomass of each organ.

\subsection{Experiment 2}

\subsection{1. ${ }^{13} \mathrm{CO}_{2}$ Pulse Labeling}

Pulse labeling of stable isotope ${ }^{13} \mathrm{C}$ was applied to a different set of trees to track the fate of assimilated carbon. Two adjacent branches (hereafter referred to as branch tandem) from the upper canopy of twelve trees were selected. For each branch tandem, the apical branch had 2-3 developing female cones (reproductive branch); the second, side branch had no cones (vegetative branch) and was equipped for isotopic labeling. In addition, on six of the twelve selected trees, girdling was performed just below the insertion of the side vegetative branch onto the apical reproductive branch by removing a $2 \mathrm{~cm}$-wide stripe of bark, phloem, and cambium, as indicated above (see Figure 1 for a schematic of the experimental approach). Vegetative side branches were exposed to ${ }^{13} \mathrm{C}$-enriched $\mathrm{CO}_{2}$, following a slightly modified protocol of that described in Kagawa et al. [32] and Miyazaki et al. [46]. For labeling, the whole vegetative branch was enclosed in a $40 \mathrm{~cm} \times 60 \mathrm{~cm}$ transparent polyethylene bag with a light transmittance above $85 \%$. Labeling bags were equipped with three rubber hoses. The first hose was used for infusion of ${ }^{13} \mathrm{CO}_{2}\left(99 \%{ }^{13} \mathrm{C}\right.$; Cambridge 
Isotope Laboratories, Andover, MA, USA) into the bag using a syringe (a in Figure 1). A second hose connected the bag to the $\mathrm{CO}_{2}$ infrared gas analyzer (Testo 340, China; accuracy $1 \%$ ) (b in Figure 1). The third hose was used for infusion of $\mathrm{CO}_{2}$-free air, prepared by passing ambient air through soda lime (c in Figure 1). The plastic bag was kept airtight by sealing it to the branch base with fat clay and wrapping the opening with a string to avoid mechanical girdling. Preliminary tests showed that after ca. $20 \mathrm{~min}$ of sealing, the concentration of $\mathrm{CO}_{2}\left(\left[\mathrm{CO}_{2}\right]\right)$ inside the bag decreased from $400 \mathrm{ppm}$ to $50 \mathrm{ppm}$. To maintain an initial $\left[\mathrm{CO}_{2}\right]$ target of ca. $400 \mathrm{ppm}, 30 \mathrm{~mL}$ of ${ }^{13} \mathrm{CO}_{2}$ were infused every $20 \mathrm{~min}$. Thus, labeled branches took up approximately $60 \mathrm{~mL}$ of ${ }^{13} \mathrm{C}$ over the duration of the one-hour labeling period. To prevent $\mathrm{CO}_{2}$ gradients in the air within the bag and water condensation on the inner surface of the plastic bag, the air inside the bag was constantly circulated with a vertically mounted electric fan ( $d$ in Figure 1). Additionally, a small amount of silica gel (ca. $10 \mathrm{~g}$ ) wrapped in gauze was placed over the electric fan to absorb water. The labeling pulse was carried out in situ on DOY 212, during the period of cone development; branches were girdled the day before labeling. Branches were exposed to ${ }^{13} \mathrm{CO}_{2}$ for $1 \mathrm{~h}$, and $4 \mathrm{~h}$ and $24 \mathrm{~h}$ afterwards both the vegetative (labeled) and adjacent, reproductive (unlabeled) branches were harvested (three girdled and ungirdled trees at each time). Samples were separated into foliar, twig, and cone tissues as indicated above. To estimate the natural abundance of ${ }^{13} \mathrm{C}$ in different organs, baseline samples were taken from different trees located far away from labeled trees $(>30 \mathrm{~m})$, thereby minimizing ${ }^{13} \mathrm{C}$ enrichment that originated from ${ }^{13} \mathrm{CO}_{2}$ efflux from labeled trees [47].
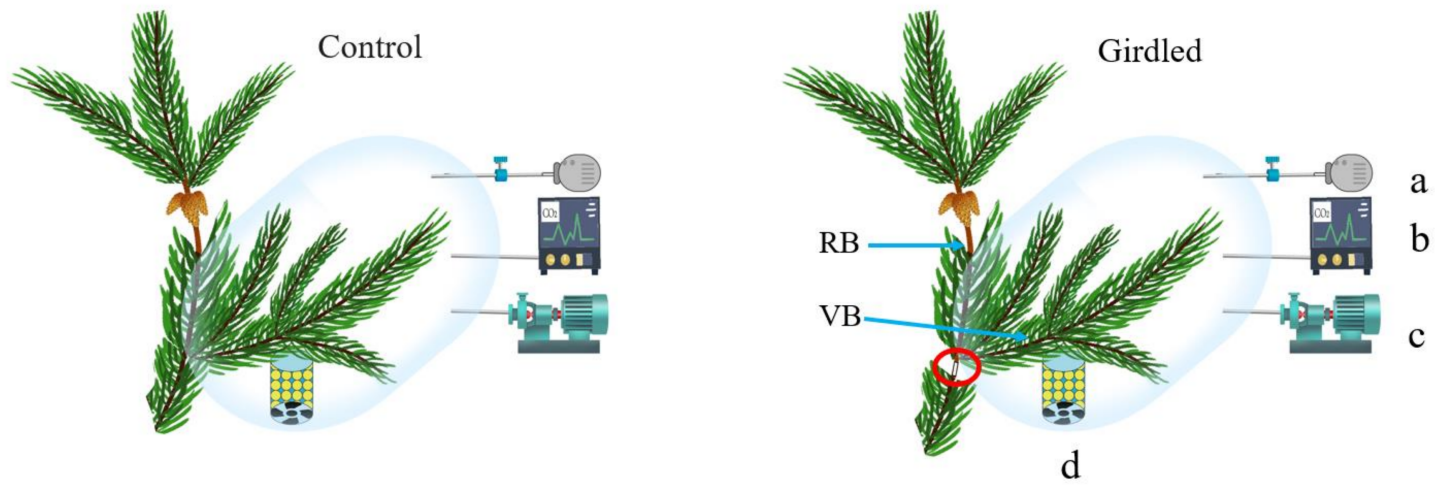

Figure 1. Scheme of the ${ }^{13} \mathrm{CO}_{2}$ pulse labeling experiment. In each selected tree, a pair of branches were either ungirdled (Control) or girdled (Girdled; red circle) $(n=6)$ at the insertion point. The lateral branch bearing no cones (i.e., vegetative branch; VB) was labeled with ${ }^{13} \mathrm{CO}_{2}$ to evaluate potential transport of assimilated ${ }^{13} \mathrm{C}$ to the apical reproductive branch (RB). a: Infusion of ${ }^{13} \mathrm{CO}_{2}$; b: $\mathrm{CO}_{2}$ infrared gas analyzer; c: Infusion of $\mathrm{CO}_{2}$-free air, prepared by passing ambient air through soda lime; d: Electric fan with silica gel.

\subsubsection{Isotopic Analysis}

About $2 \mathrm{mg}$ samples were weighed in tinfoil caps using a microbalance (accuracy $0.1 \mu \mathrm{g}$; Sartorius SE2 Mettler Toledo XP2U). Samples were analyzed with an elemental analyzer (NC 2500; CE Instruments, Milan, Italy) and an isotope ratio mass spectrometer (MAT 252; Thermo Electron, Bremen, Germany) to determine ${ }^{13} \mathrm{C}$ abundance $\left(\mathrm{a}^{13} \mathrm{C}\right)$, expressed here in delta notation relative to the Vienna PeeDee belemnite (V-PDB) standard $\left(\delta^{13} \mathrm{C}, \%\right)$. The standard deviation for replicate combustions of our internal standards (DL-alanine) was $0.07 \%$.

The excess of ${ }^{13} \mathrm{C}$ was calculated according to Kagawa et al. [32] and Ge et al. [30] as the difference in $\mathrm{a}^{13} \mathrm{C}$ between labeled and baseline samples:

$$
\text { Excess }{ }^{13} \mathrm{C}=\mathrm{a}^{13} \mathrm{Csample}-\mathrm{a}^{13} \mathrm{Cbsl}
$$


The assimilation of labeled ${ }^{13} \mathrm{C}(\mathrm{g})$ into foliar (CF), twig (CT), and cone (CC) tissues was calculated as:

$$
{ }^{13} \mathrm{C} \text { assimilation }=\text { Excess }{ }^{13} \mathrm{C} \times[\mathrm{C}] \times \mathrm{DB}
$$

where $[\mathrm{C}]\left(\mathrm{g} \mathrm{g}^{-1}\right)$ and $\mathrm{DB}(\mathrm{g})$ are the $\mathrm{C}$ concentration and the dry biomass of the corresponding tissue. The total assimilation of labeled ${ }^{13} \mathrm{C}$ was then estimated separately for vegetative and reproductive branches as the sum of ${ }^{13} \mathrm{C}$ assimilated in foliar, twig, and reproductive tissues:

$$
{ }^{13} \mathrm{Ctotal}={ }^{13} \mathrm{CF}+{ }^{13} \mathrm{CT}+{ }^{13} \mathrm{CC}
$$

Finally, we estimated the percentage of retention of ${ }^{13} \mathrm{C}$ assimilated in vegetative branches relative to the amount of ${ }^{13} \mathrm{C}$ assimilated by both vegetative and reproductive branches.

\subsection{Statistical Analyses}

Statistical analyses were performed using SPSS 21.0 (SPSS, Chicago, IL, USA). For Experiment 1, linear mixed models were adjusted per surveyed variable, considering tree as a random factor. Girdling, defoliation, and their interaction were treated as fixed factors. When significant, post-hoc LSD tests were applied for multiple comparisons of treatment combinations. Surveyed variables include branch diameter and length, living cone number, twig and cone survival rate, foliar, twig, cone and seed biomass, and tissue [NSC] and NSC content. For Experiment 2, mean values and the standard error of $\delta^{13} \mathrm{C}$ and ${ }^{13} \mathrm{C}$ assimilations were separately calculated for each tissue (foliar, twig, and cone), type of branch (vegetative and reproductive), treatment (girdled and ungirdled), and for both harvesting periods ( $4 \mathrm{~h}$ and $24 \mathrm{~h}$ after the labeling pulse). A two-way ANOVA was used for both vegetative and reproductive branches to determine the effect of harvesting time and girdling on the $\delta^{13} \mathrm{C}$ and ${ }^{13} \mathrm{C}$ assimilations within each branch $\times$ tissue combination.

\section{Results}

\subsection{Experiment 1}

\subsubsection{Branch Growth}

Girdling had a major effect on branch growth in comparison with defoliation. The interaction between defoliation intensity and girdling was not significant at $p<0.05$ for most of the surveyed variables (Table S1).

Defoliation (of 50\% and 100\%) of two-year-old needles had a minor, generally insignificant effect on the production of new needles and the development of new, one-year-old twigs (Figure 2a-d). Girdling resulted in short, poorly-developed one-year-old twigs that hardly bore any needles (Figure 2a-d, Figure S2). Girdling effects on two-year-old twigs were less evident than in one-year-old twigs but still significant, independently of defoliation intensity (Figure 2e-f). All twigs of ungirdled branches survived the study period, but none survived in the girdled branches (Figure S3a). 

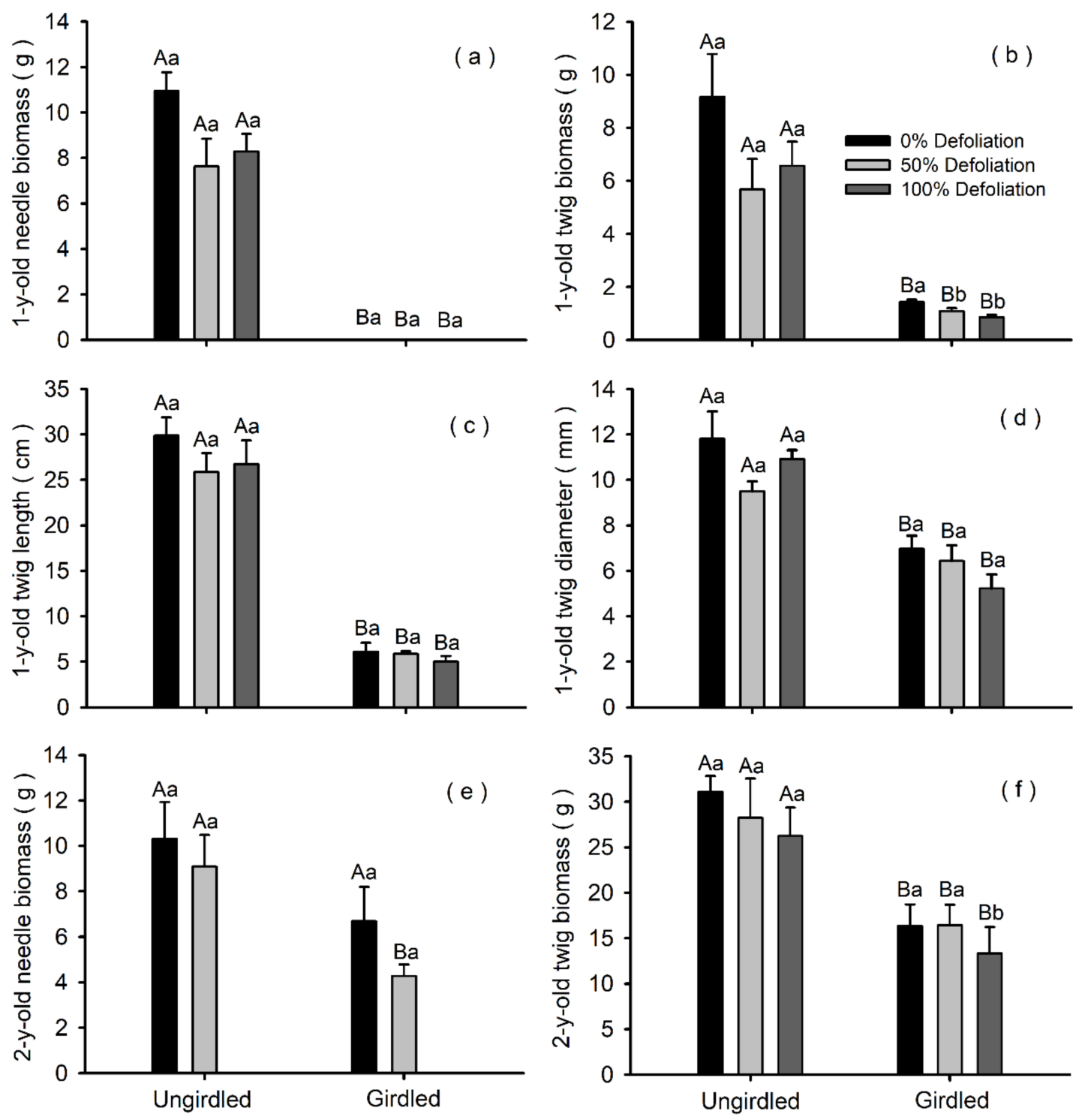

Figure 2. Needle and twig biomass and twig dimensions (length and diameter) of one-year-old (Y1; a-d) and two-year-old $(Y 2 ; \mathbf{e}, \mathbf{f})$ Pinus koraiensis branches in response to girdling and defoliation treatments. One-year-old needle biomass was nil in girdled branches. Bars and arrows represent the mean and corresponding standard error, respectively, per treatment combination. Different capital letters indicate a significant effect of girdling for a given defoliation intensity $(p<0.05)$. Different lowercase letters indicate significant differences among defoliation intensities for a given girdling group $(p<0.05)$. Means were compared using LSD tests.

\subsubsection{Reproductive Output}

Girdling had a major effect on reproductive output (i.e., mature cone number, cone biomass, and seed biomass; Figure $3 \mathrm{a}-\mathrm{c}$ ). The cones of girdled branches, visible before girdling, stopped their development and produced no sound seed. That is, cone survival rate was nil in girdled branches and 100\% in ungirdled branches (Figure S3b). In comparison, defoliation had no significant effect on these metrics, independent of the girdling treatment (Figure 3a-c). 

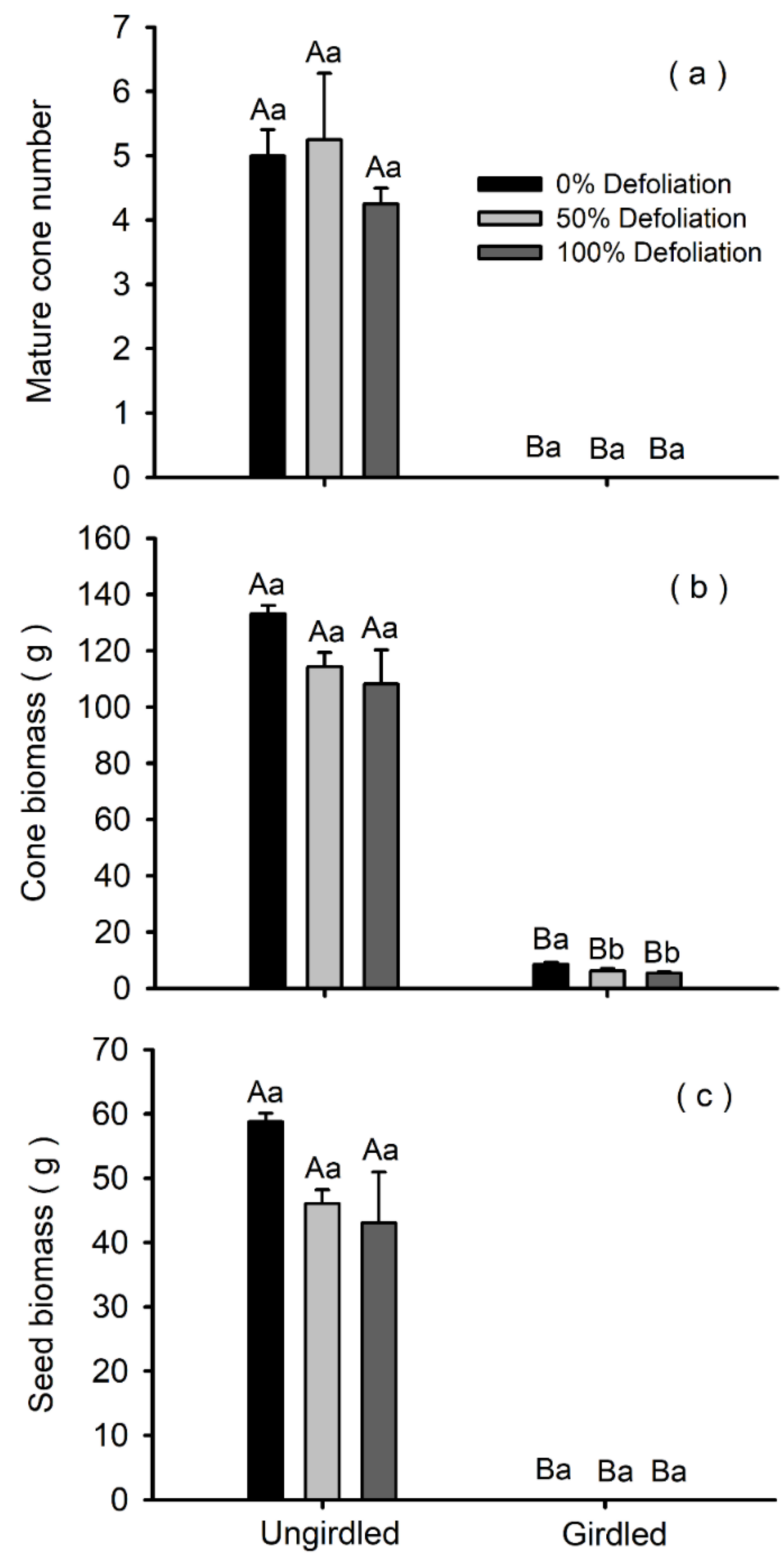

Figure 3. Number of mature cones (a) and cone and seed biomass (b-c) in response to girdling and defoliation treatments in Pinus koraiensis. The number of mature cones and the seed biomass were nil in girdled branches. Bars and arrows represent the mean and corresponding standard error, respectively, per treatment combination. Different capital letters indicate a significant effect of girdling for a given defoliation intensity $(p<0.05)$. Different lowercase letters indicate significant differences among defoliation intensities for a given girdling group $(p<0.05)$. Means were compared using LSD tests.

\subsubsection{NSC Concentration and Content}

Girdling had a significant, negative effect on the [NSC] of one-year-old twigs and needles (Figure 4a,b), two-year-old twigs and needles (Figure 4c,d), and cones and seeds (Figure $4 \mathrm{e}, \mathrm{f})$. The interaction between defoliation and girdling treatments was significant for [SS] and [starch] in most of the tissues surveyed ( $p<0.05$; Figure 4 and Table S1). Thus, defoliation had a significant, negative effect on [NSC], but only in the case of girdled branches. In these branches, [NSC] and [SS] decreased with increasing defoliation intensity in one- and two-year-old twigs (Figure 4a,c), and in the cones (Figure 4e); similar but less marked declines were observed for [starch]. In ungirdled branches, defoliation had a more 
moderate impact. The results for NSC content, calculated from the product of [NSC] and organ biomass, were similar (Figure S4).
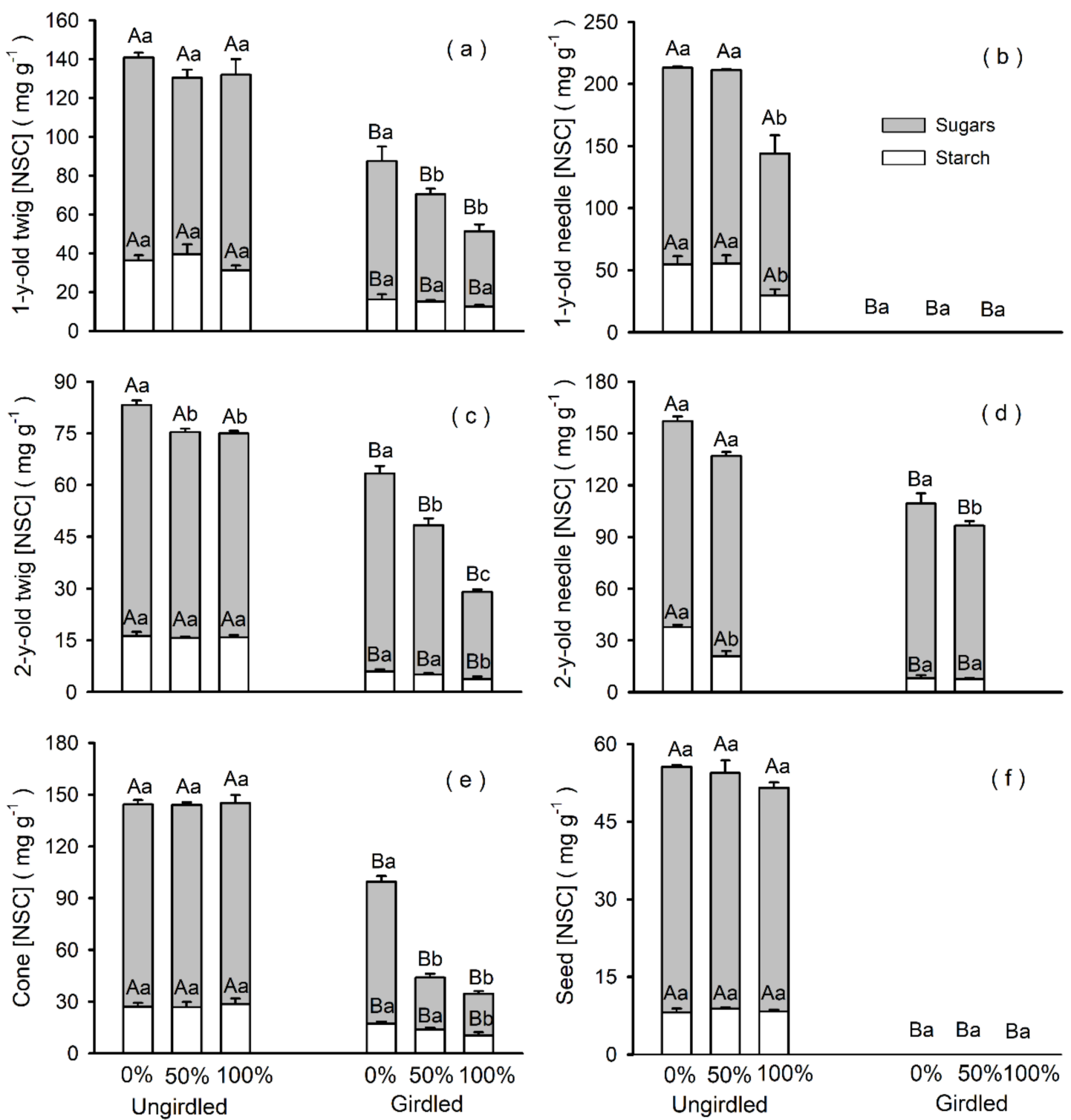

Figure 4. Non-structural carbohydrate concentration ([NSC]) of one-year-old (Y1; a, b and e) and two-year-old (Y2; c, d and f) Pinus koraiensis branches in response to girdling and defoliation treatments. One-year-old needle and seed [NSC] was nil in girdled branches. Bars and arrows represent the mean and corresponding standard error, respectively, per treatment combination. Different capital letters indicate a significant effect of girdling for a given defoliation intensity $(p<0.05)$. Different lowercase letters indicate significant differences among defoliation intensities for a given girdling group $(p<0.05)$. Means were compared using LSD tests.

\subsection{Experiment 2}

\subsection{1. $\delta^{13} \mathrm{C}$ in Needles, Twigs, and Cones}

To evaluate the contribution of photoassimilates imported from vegetative branches to the development of reproductive branches, $\delta^{13} \mathrm{C}$ in tissues from vegetative $\left({ }^{13} \mathrm{C}\right.$-labeled $)$ and reproductive (unlabeled) branches were analyzed (Figure 5). The effects of harvesting time, girdling, and harvesting time $\times$ girdling on mean $\delta^{13} \mathrm{C}$ values were statistically significant for all tissues in both vegetative and reproductive branches $(p<0.05$; Figure 5 and Table S2). 

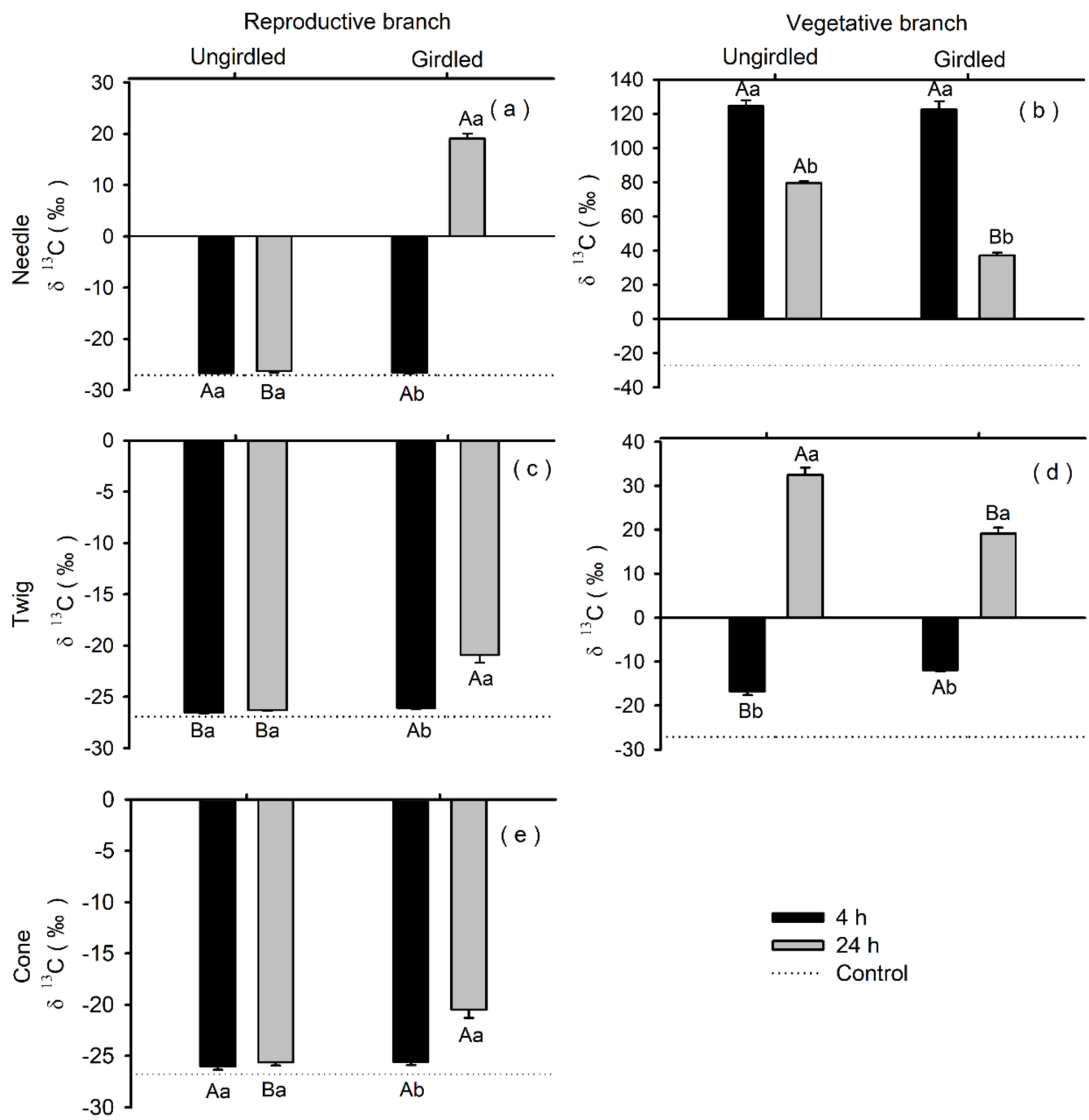

(d)

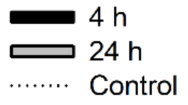

Figure 5. Carbon isotopic composition $\left(\delta^{13} \mathrm{C}\right)$ in needle $(\mathbf{a}, \mathbf{b})$, twig $(\mathbf{c}, \mathbf{d})$, and cone $(\mathbf{e})$ tissues after $4 \mathrm{~h}$ and $24 \mathrm{~h}$ of the ${ }^{13} \mathrm{CO}_{2}$ labeling pulse to which vegetative branches of Pinus koraiensis were subjected. Each tandem of branches was girdled or remained ungirdled $(n=6)$. Dotted lines indicate the baseline $\delta^{13} \mathrm{C}$ measured in unlabeled trees (control). Bars and arrows represent the mean and corresponding standard error. Different capital letters indicate significant differences between girdling treatment levels for a given harvesting time $(p<0.05)$. Different lowercase letters indicate significant differences between harvesting times for a given girdling treatment $(p<0.05)$. Means were compared using LSD tests.

Mean baseline $\delta^{13} \mathrm{C}$ in needle, twig, needle, and cone tissues sampled in unlabeled trees ranged from $-27.4 \%$ to $-26.6 \%$ (see dotted lines in Figure 5). Sampling time largely affected $\delta^{13} \mathrm{C}$ throughout branch-types and tissues. After labeling, mean $\delta^{13} \mathrm{C}$ was positive and highest in needles of vegetative branches, especially after $4 \mathrm{~h}$ of the labeling-pulse, and decreased from vegetative to reproductive branches (Figure $5 a, b)$. Twenty-four $h$ after labeling, $\delta^{13} \mathrm{C}$ decreased in the needles, and increased in twigs of vegetative branches (reaching positive values) and in the needles of reproductive branches under the girdling treatment (i.e., export/import of ${ }^{13} \mathrm{C}$-photoassimilates was arrested; Figure 1; Figure 5a-d). Overall, the effect of girdling on tissue $\delta^{13} \mathrm{C}$ was modest $4 \mathrm{~h}$ after labeling and considerable higher $24 \mathrm{~h}$ after labeling. At this time and compared to ungirdled branches, girdled branches exhibited lower $\delta^{13} \mathrm{C}$ in needles and twigs of vegetative (labeled) branches, and higher $\delta^{13} \mathrm{C}$ in needles, twigs, and cones of reproductive (unlabeled) branches (Figure 5). 


\subsection{2. ${ }^{13} \mathrm{C}$-photoassimilate Allocation}

Relative to the total amount of recovered label, allocation of ${ }^{13} \mathrm{C}$-photoassimilates in the vegetative (labeled) branches reached their maximum $4 \mathrm{~h}$ after labeling: $93.8 \%$ and $95.5 \%$ in girdled and ungirdled branches, respectively (Figure 6). Assimilation in needles contributed to the largest extent to these percentages $(77.1 \%$ and $86.2 \%$ in girdled and ungirdled branches, respectively). Twenty-four hours post-labeling, ${ }^{13} \mathrm{C}$ allocation was similar in ungirdled branches, but remarkably different in girdled branches. At this time, the amount of label detected in vegetative branches accounted for $54.6 \%$ and $92.2 \%$ of the recovered label in girdled and ungirdled branches, respectively (Figure 6); in girdled branches, allocation of ${ }^{13} \mathrm{C}$-photoassimilates reached $14.5 \%, 17.2 \%$, and ${ }^{13} .7 \%$ in twigs, needles, and cones of reproductive branches, respectively.

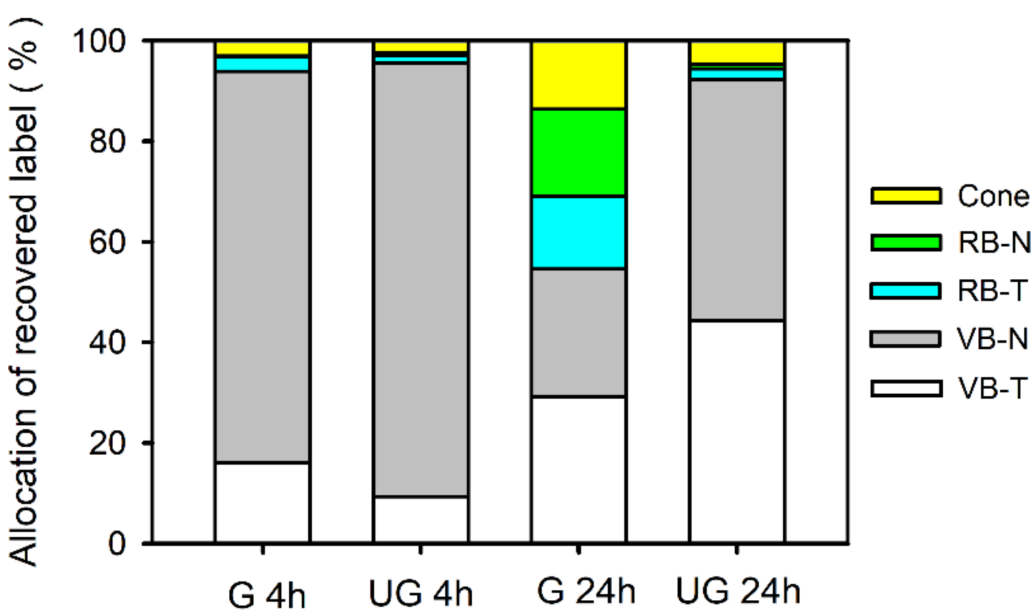

Figure 6. Allocation of ${ }^{13} \mathrm{C}$ photoassimilates throughout tissues (needles, twigs, and cones) of vegetative (VB) and reproductive (RB) branches after $4 \mathrm{~h}$ and $24 \mathrm{~h}$ of ${ }^{13} \mathrm{C}$ pulse labeling in VB of Pinus koraiensis. Each tandem of branches were girdled $(\mathrm{G})$ or remained ungirdled (UG) $(n=6)$. Mean values (\%) are given relative to the total amount of label recovered across sampled tissues and branch types. Abbreviations: RB-N: Needles of reproductive branch; RB-T: Twig of reproductive branch; VB-N: Needles of vegetative branch; VB-T: Twig of vegetative branch.

\section{Discussion}

\subsection{Girdling and Defoliation Denote Translocation of Photoassimilates among} Neighboring Branches

Tree branches are considered as $C$ autonomous when assimilates from local photosynthesis and local reservoirs are self-sufficient to fulfill $\mathrm{C}$ requirements for maintenance, growth, and reproductive metabolism. Numerous examples in literature demonstrate that branches can be fully $\mathrm{C}$ autonomous $[8,10,12,48]$. For example, by applying a similar girdling by defoliation treatment combination to the one used here, Hoch [8] found that branches of three tree angiosperm species were $\mathrm{C}$ autonomous. Other examples, however, illustrate a gradient between completely $\mathrm{C}$ autonomous and completely $\mathrm{C}$ dependent branches $[14,29,37,49]$. Our results clearly refute the idea of $C$ autonomy in cone-bearing branches of $P$. koraiensis, which exhibited a strong dependency on distant $C$ sources. Defoliation (of two-year-old needles) in ungirdled branches had little effect on overall branch development and growth. Specifically, the number of newly emerged one-year-old needles and cones per branch, branch dimensional traits (length and diameter), and biomass of different organs (needles, twigs, and cones) tended to decrease with increasing defoliation intensity; this reduction, however, was not significant for any of these variables (Figures 2 and 3). Furthermore, branch dieback or cone abscission did not occur after defoliation. The mostly neutral response to defoliation suggests a limited role of local foliar photosynthesis of previous-year needles on branch development and reproduction, and therefore a substantial contribution of other $C$ sources. These $C$ sources are likely located 
in adjacent branches or the main stem, as found in orchard species such as Japanese pear (Pyrus pyrifolia Nakai) [37] and hazelnut (Corylus avellana L.) [29]. Carbon shortage due to defoliation could have been mitigated by local reserves stored prior to defoliation and photoassimilates from chloroplast-containing cells in woody tissues [50,51], developing reproductive structures of green cones [52,53], and even from new needles grown after defoliation (see Figure S1). Nevertheless, branch response to girdling further supports the idea of a strong reliance on imported C. If local photoassimilates or NSC reserves constitute a primary $\mathrm{C}$ source, we would expect a minor effect of girdling on branch and cone development [8]. However, and regardless of defoliation intensity, phloem disruption by girdling and subsequent inability to import $C$ significantly constrained branch development, as denoted here by the lower number of needle and living cones per branch, shorter and narrower twigs, and reduced biomass of different organs. Again, although these reductions in girdled branches tended to be aggravated by defoliation intensity, the effect of defoliation was minor relative to that of girdling. Notably, the rate of branch death and cone abscission drastically rose up to $100 \%$ in girdled branches, suggesting that carbohydrate deficiency might contribute to branch dieback, as previously observed in pistachio (Pistacia vera L.) [1] and coffee (Coffea arabica L.) [52]. In summary, branch response to combined treatments of girdling and defoliation indicates that local photoassimilates and $C$ reserves are insufficient to support development of female cones and branches in P. koraiensis, which largely rely on imported C, supporting the preliminary work performed on this species [40,54].

In cases of temporal and spatial mismatches between $C$ supply and demand, trees remobilize stored $C$ throughout organs to satisfy requirements from $C$ sinks. A substantial fraction of stored NSC is consumed for reproductive purposes, from floral primordia initiation to seed development, especially during masting years [2,13,34,55]. Here, we applied the phenol sulphuric method to quantify and compare branch NSC status among treatments. Thus, although [NSC] estimates are adequate for our purpose, absolute [NSC] values should be taken with caution for literature comparison [56]. Girdling resulted in a major, significant reduction in [NSC] across needles, one-year-old twigs, two-year-oldtwigs, cones, and seeds. However, although the effect of defoliation was comparatively small, significant reductions in [NSC] across needles, twigs, and cones were observed following defoliation, more evidently in girdled branches (Figure 4). Differences in [NSC] were not uniquely driven by variation in [starch], which could be expected following starch hydrolysis to maintain stability [SS], and thus, plant metabolic activity [22,57]. Depletion of [SS] following combined treatments of girdling and defoliation might suggest small SS buffer pools during periods of constrained $C$ gain in P. koraiensis, as was similarly observed for $P$. radiata [58]. Accordingly, a relatively stronger effect of defoliation on [NSC], rather than on volumetric growth and biomass throughout sampled tissues, may also suggest that branches prioritize development over storage, hereby exhibiting a non-conservative behavior in terms of $\mathrm{C}$ use economy. In particular, the most drastic reduction in [NSC] occurred in cones and seeds of girdled branches, while reductions in needle and branch [NSC] were comparatively limited. Rapid depletion of NSC in cones clearly denotes preferential resource allocation in foliar and twig tissues for survival to the detriment of reproductive organs, thereby constraining seed yield when facing physiological stress. As mentioned above, phloem disruption by girdling eventually led to branch dieback. Nevertheless, C starvation might not be the only trigger for branch and cone mortality, as NSC reserves were reduced but not completely consumed in girdled branches (Figure 4). Incomplete depletion of NSC in dead organs was similarly found in non-functional heartwood of ten temperate species of different wood anatomy [59]. Secondary effects of girdling related to wound desiccation and partial hydraulic dysfunction might have exacerbated the detrimental effects of $C$ shortage for branch survival, as it remains difficult to discern between the interacting factors triggering leaf, canopy, and tree dieback [60]. 


\subsection{Branch C Autonomy Depends on the Source-Sink Balance}

Pulse labeling is widely applied to track $C$ movement across tree organs and advance our understanding on tree $\mathrm{C}$ allocation dynamics [61]. For instance, ${ }^{13} \mathrm{CO}_{2}$ has proved useful as a stable isotopic tracer to test whether labeled assimilates are translocated among adjacent branches $[10,14,37,46]$. A high degree of branch $C$ autonomy was suggested for Siberian alder (Alnus hirsuta var. sibirica), hornbeam (Carpinus betulus L.), and peach [Prunus persica (L.) Batsch], as ${ }^{13} \mathrm{C}$ enrichment was not detected in unlabeled reproductive shoots nearing labeled ones $[10,36,49]$. Here, to facilitate isotope tracking in field-grown trees, younger and smaller trees than those manipulated in Experiment 1 were labeled and monitored. For this, vegetative branches were exposed to ${ }^{13} \mathrm{CO}_{2}$ during the phenological stage of cone expansion, the period of seed reserve accumulation, and kernel filling [62]. In this way, the C-sink strength of unlabeled cone-bearing branches was maximal, to ensure a strong competition for NSC between these branches and the labeled vegetative branches [18,63]. Significant ${ }^{13} \mathrm{C}$ enrichment in foliar, twig, and reproductive tissues of cone-bearing branches, clearly observed $24 \mathrm{~h}$ after the ${ }^{13} \mathrm{C}$ pulse in the girdling treatment (Figure 5), evidences $\mathrm{C}$ import from neighboring branches and further supports insights gained from defoliation and girdling treatments performed in Experiment 1. Similarly, and counter to the idea of branch C autonomy, translocation of labeled assimilates between adjacent branches has been observed in fruits and branches of Styrax obassia Sieb. et Zucc. [46], Japanese beech (Fagus crenata Blume) [64], pear (Pyrus spp.) [37], and Chinese chestnut (Castanea mollissima Bl.) [65].

Our labeling approach allowed us to evaluate $C$ allocation patterns depending on harvesting time ( $4 \mathrm{~h}$ vs. $24 \mathrm{~h}$ post-labeling) and on the alteration of source-sink relationships by means of manipulative girdling. Here, the largest fraction of ${ }^{13} \mathrm{C}$ recovered in branch tissues was found in vegetative branches $(>95 \%) 4 \mathrm{~h}$ after the labeling pulse, mostly in foliar tissues (77-86\%), irrespective of girdling application (Figure 6). However, $24 \mathrm{~h}$ after the pulse, ${ }^{13} \mathrm{C}$ allocation was clearly affected by girdling applied just below the junction of the branch tandem (composed by one vegetative and one reproductive branch). In ungirdled branches, the largest fraction of label remained within vegetative branches ( $50 \%$ and $44 \%$ in foliar and twig tissues, respectively), while little was found in cone-bearing branches $(6 \%)$. Limited label translocation denotes substantial $\mathrm{C}$ requirements of vegetative branches for growth, respiration, and storage for future development [14]. Contrastingly, when girdling was applied, a substantial fraction of the label was detected in cone-bearing branches $(17,14$, and $13 \%$ in foliar, twig, and reproductive tissues, respectively). Such a remarkable difference between treatments highlights the major role of $C$ source-sink relations in determining spatial $C$ allocation patterns. Because each branch tandem was close to 4-6 additional vegetative branches, we hypothesize that girdling impeded both $\mathrm{C}$ import from nearby unlabeled branches to reproductive branches and $\mathrm{C}$ export from labeled vegetative branches to the main stem, thereby exacerbating the [NSC] gradient along the girdled branch tandem. According to Münch's theory, phloem flow occurs following an osmotically driven pressure gradient in phloem sieve elements [3]. Therefore, greater differences in [NSC] between vegetative and cone-bearing branches likely enhanced phloem loading and unloading, respectively. Similar to our results, labeling exercises in Prunus persica [36] and Camellia sasanqua Thunb. [14] proved the major effect of the C sink strength in translocation rates of labeled $\mathrm{C}$. By manipulative alteration of the sourcesink balance, either by defoliation, fruit removal, or girdling, ${ }^{13} \mathrm{C}$ enrichment in different tissues of labeled and unlabeled branches largely changed, denoting that the degree of branch $\mathrm{C}$ autonomy is not just a species-specific trait but variable and highly dependent on environmental or experimental factors.

\section{Conclusions}

Girdling led to major limitations in branch volumetric development, biomass, and NSC pools across foliar, twig, and reproductive tissues in adult P. koraiensis trees. Although these variables tended to decrease with defoliation intensity, the defoliation effect was 
relatively limited on branch growth and cone development. Both observations suggest that the cone-bearing branches are not $C$ autonomous and that they need to import $C$ from neighboring branches to fully develop. Accordingly, ${ }^{13} \mathrm{C}$ enrichment in unlabeled conebearing branches evidenced $C$ translocation from labeled vegetative branches, especially when the main branch supporting both branches was girdled. These results help to better understand the source-sink relations behind cone development in P. koraiensis, which can guide forest management practices in cone-producing species, as a first step to eventually enhance seed production during masting years.

Supplementary Materials: The following are available online at https://www.mdpi.com/article/ 10.3390/f12091257/s1, Figure S1: One-year-old (Y1) and two-years-old (Y2) shoots of reproductive branches of Pinus koraiensis trees monitored for "Experiment 1", Figure S2: Visual example of twig growth and cone development in girdled and defoliated branches at harvesting of one Pinus koraiensis tree manipulated for "Experiment 1". Regardless of the defoliation intensity, branch and cone growth and survival rates were higher in ungirdled branches, Figure S3: Twig and cone survival rate in Pinus koraiensis branches in response to girdling and defoliation treatments for "Experiment 1". Twig and cone survival rate values were nil in girdled branches, Figure S4: Non-structural carbohydrate content (NSC) of one-year-old (Y1; a, b and e) and two-year-old (Y2; c, d, and f) Pinus koraiensis branches in response to girdling and defoliation treatments for "Experiment 1". One-year-old needle and seed NSC were nil in girdled branches. Bars and arrows represent the mean and corresponding standard error, respectively, per treatment combination. Different capital letters indicate a significant effect of girdling for a given defoliation intensity $(p<0.05)$. Different lowercase letters indicate significant differences among defoliation intensities for a given girdling group $(p<0.05)$. Means were compared using LSD tests, Table S1: Effect of girdling (girdled and ungirdled) and defoliation ( $0 \%$, $50 \%$ and $100 \%$ intensity) and their interaction on branch growth and NSC concentrations in Pinus koraiensis trees (Experiment 1), Table S2: F-value of two-way ANOVAs testing the effects of girdling (girdled and ungirdled) and harvesting time $\left(4 \mathrm{~h}\right.$ and $24 \mathrm{~h}$ ) on the carbon isotopic composition $\left(\delta^{13} \mathrm{C}\right)$ and ${ }^{13} \mathrm{C}$ assimilation $\left({ }^{13} \mathrm{C}\right)$ throughout branch tissues (needles, twigs and cones) in reproductive and vegetative branches of Pinus koraiensis, and on the amount of undetected label after ${ }^{13} \mathrm{C}$ labelling-pulse applied to vegetative branches (Experiment 2).

Author Contributions: H.W., D.Y., P.Z. and H.S. conceived and designed the study; H.W., D.Y. and J.Z. collected plant material and performed the measurements; H.W. analyzed the data, guided by J.R.-C. and R.L.S.; H.W., J.R.-C. and R.L.S. prepared the first draft of the manuscript; P.Z., H.S., J.Z. and D.Y. revised the manuscript. All authors have read and agreed to the published version of the manuscript.

Funding: This work was supported by the Fundamental Research Funds for the Central Universities (Grant No. 2572018AA03); the National Key Research and Development Program of China (Grant No. 2017YFD0600601); the National Natural Science Foundation of China (Grant No.31700551); and the Key Research and Development Projects in Heilongjiang Province (Grant No. GA21B005). HBW acknowledges funding from China Scholarship Council (CSC number 201906600024) and RLS acknowledges funding from the Spanish Ministry of Science, Innovation and Universities (Juan de la Cierva Programme, Grant IJC2018-036123-I).

Institutional Review Board Statement: Not applicable.

Informed Consent Statement: Not applicable.

Data Availability Statement: The experimental data used in the study are available from the corresponding author on reasonable request.

Conflicts of Interest: The authors declare that they have no conflict of interest.

\section{References}

1. Elloumi, O.; Ghrab, M.; Mimoun, M.B. Effects of flower buds removal on seasonal starch storage and mobilization in fruiting and non-fruiting branches of pistachio trees cv. Mateur under dry and warm climate. Sci. Hortic. 2014, 172, 19-25. [CrossRef]

2. Pearse, I.S.; Koenig, W.D.; Kelly, D. Mechanisms of mast seeding: Resources, weather, cues, and selection. New Phytol. 2016, 212, 546-562. [CrossRef] 
3. Knoblauch, M.; Knoblauch, J.; Mullendore, D.L.; Savage, J.A.; Babst, B.A.; Beecher, S.D.; Dodgen, A.C.; Jensen, K.H.; Holbrook, N.M. Testing the Münch hypothesis of long distance phloem transport in plants. Elife 2016, 5, e15341. [CrossRef]

4. Lough, T.J.; Lucas, W.J. Integrative plant biology: Role of phloem long-distance macromolecular trafficking. Annu. Rev. Plant Biol. 2006, 57, 203-232. [CrossRef]

5. Thompson, G.A.; Schulz, A. Macromolecular trafficking in the phloem. Trends Plant Sci. 1999, 4, 354-360. [CrossRef]

6. Gifford, R.M.; Evans, L.T. Photosynthesis, carbon partitioning, and yield. Annu. Rev. Plant Biol. 1981, 32, 485-509. [CrossRef]

7. Watson, M.A. Integrated physiological units in plants. Trends Ecol. Evol. 1986, 1, 119-123. [CrossRef]

8. Hoch, G. Fruit-bearing branchlets are carbon autonomous in mature broad-leaved temperate forest trees. Plant Cell Environ. 2005, 28, 651-659. [CrossRef]

9. Lacointe, A.; Deleens, E.; Ameglio, T.; Joanis, B.S.; Lelarge, C.; Vandame, M.; Song, G.C.; Daudet, F.A. Testing the branch autonomy theory: $\mathrm{A}{ }^{13} \mathrm{C} /{ }^{14} \mathrm{C}$ double-labelling experiment on differentially shaded branches. Plant Cell Environ. 2004, 27, 1159-1168. [CrossRef]

10. Hasegawa, S.; Koba, K.; Tayasu, I.; Takeda, H.; Haga, H. Carbon autonomy of reproductive shoots of Siberian alder (Alnus hirsuta var. sibirica). J. Plant Res. 2003, 116, 183-188. [CrossRef] [PubMed]

11. Sprugel, D.; Hinckley, T.; Schaap, W. The theory and practice of branch autonomy. Annu. Rev. Ecol. Evol. Syst. 1991, 22, 309-334. [CrossRef]

12. Obeso, J. Effects of defoliation and girdling on fruit production in Ilex aquifolium. Funct. Ecol. 1998, 12, 486-491. [CrossRef]

13. Miyazaki, Y. Dynamics of internal carbon resources during masting behavior in trees. Environ. Res. 2013, 28, 143-150. [CrossRef]

14. Oitate, H.; Noguchi, K.; Sone, K.; Terashima, I.; Suzuki, A.A. Patterns of photoassimilate translocation to reproductive shoots from adjacent shoots in Camellia sasanqua by manipulation of sink-source balance between the shoots. J. Plant Res. 2011, 124, 131-136. [CrossRef]

15. Li, Y.N.; Yang, D.M.; Sun, S.C.; Gao, X.M. Effects of twig size on biomass allocation within twigs and on Lamina area supporting efficiency in Rhododendron: Allometric scaling analyses. Chin. J. Plant Ecol. 2008, 32, 1175. [CrossRef]

16. Millard, P.; Grelet, G. Nitrogen storage and remobilization by trees: Ecophysiological relevance in a changing world. Tree physiol. 2010, 30, 1083-1095. [CrossRef]

17. Weiskittel, A.R.; Maguire, D.A.; Monserud, R.A. Response of branch growth and mortality to silvicultural treatments in coastal Douglas-fir plantations: Implications for predicting tree growth. For. Ecol. Manag. 2007, 251, 182-194. [CrossRef]

18. Crone, E.E.; Rapp, J.M. Resource depletion, pollen coupling, and the ecology of mast seeding. Ann. N. Y. Acad. Sci. 2014, 1322, 21-34. [CrossRef]

19. Asao, S.; Ryan, M.G. Carbohydrate regulation of photosynthesis and respiration from branch girdling in four species of wet tropical rain forest trees. Tree Physiol. 2015, 35, 608-620. [CrossRef]

20. Moreira, R.A.; Fernandes, D.R.; da Cruz, M.d.C.M.; Lima, J.E.; de Oliveira, A.F. Water restriction, girdling and paclobutrazol on flowering and production of olive cultivars. Sci. Hortic. 2016, 200, 197-204. [CrossRef]

21. Mediene, S.; Jordan, M.O.; Pagès, L.; Lebot, J.; Adamowicz, S. The influence of severe shoot pruning on growth, carbon and nitrogen status in young peach trees (Prunus persica). Tree Physiol. 2002, 22, 1289-1296. [CrossRef] [PubMed]

22. Miranda, J.C.; Rodríguez-Calcerrada, J.; Pita, P.; Saurer, M.; Oleksyn, J.; Gil, L. Carbohydrate dynamics in a resprouting species after severe aboveground perturbations. Eur. J. For. Res. 2020, 139, 841-852. [CrossRef]

23. Piper, F.I.; Gundale, M.J.; Fajardo, A. Extreme defoliation reduces tree growth but not $\mathrm{C}$ and N storage in a winter-deciduous species. Ann. Bot. 2015, 115, 1093-1103. [CrossRef]

24. Rubio-Cuadrado, Á.; Gómez, C.; Rodríguez-Calcerrada, J.; Perea, R.; Gordaliza, G.G.; Camarero, J.J.; Montes, F.; Gil, L. Differential response of oak and beech to late frost damage: An integrated analysis from organ to forest. Agric. For. Meteorol. 2021, $297,108243$. [CrossRef]

25. Barry, K.M.; Quentin, A.; Eyles, A.; Pinkard, E.A. Consequences of resource limitation for recovery from repeated defoliation in Eucalyptus globulus Labilladière. Tree Physiol. 2012, 32, 24-35. [CrossRef]

26. Pinkard, E.A.; Eyles, A.; O'Grady, A.P. Are gas exchange responses to resource limitation and defoliation linked to source: Sink relationships? Plant Cell Environ. 2011, 34, 1652-1665. [CrossRef]

27. Agusti, M.; Andreu, I.; Juan, M.; Almela, V.; Zacarias, L. Effects of ringing branches on fruit size and maturity of peach and nectarine cultivars. J. Hortic. Sci. Biotechnol. 1998, 73, 537-540. [CrossRef]

28. Poirier-Pocovi, M.; Lothier, J.; Buck-Sorlin, G. Modelling temporal variation of parameters used in two photosynthesis models: Influence of fruit load and girdling on leaf photosynthesis in fruit-bearing branches of apple. Ann. Bot. 2018, 121, 821-832. [CrossRef]

29. Pasqualotto, G.; Carraro, V.; De Gregorio, T.; Huerta, E.S.; Anfodillo, T. Girdling of fruit-bearing branches of Corylus avellana reduces seed mass while defoliation does not. Sci. Hortic. 2019, 255, 37-43. [CrossRef]

30. Ge, Z.M.; Zhou, X.; Kellomäki, S.; Biasi, C.; Wang, K.Y.; Peltola, H.; Martikainen, P.J. Carbon assimilation and allocation $\left({ }^{13} \mathrm{C}\right.$ labeling) in a boreal perennial grass (Phalaris arundinacea) subjected to elevated temperature and $\mathrm{CO}_{2}$ through a growing season. Environ. Exp. Bot. 2012, 75, 150-158. [CrossRef]

31. Kagawa, A.; Sugimoto, A.; Maximov, T.C. Seasonal course of translocation, storage and remobilization of ${ }^{13} \mathrm{C}$ pulse-labeled photoassimilate in naturally growing Larix gmelinii saplings. New Phytol. 2006, 171, 793-804. [CrossRef] 
32. Blessing, C.H.; Werner, R.A.; Siegwolf, R.; Buchmann, N. Allocation dynamics of recently fixed carbon in beech saplings in response to increased temperatures and drought. Tree Physiol. 2015, 35, 585-598. [CrossRef] [PubMed]

33. Gavrichkova, O.; Liberati, D.; de Dato, G.; Jaoudé, R.A.; Brugnoli, E.; de Angelis, P.; Guidolotti, G.; Pausch, J.; Spohn, M.; Tian, J.; et al. Effects of rain shortage on carbon allocation, pools and fluxes in a Mediterranean shrub ecosystem-A ${ }^{13} \mathrm{C}$ labelling field study. Sci. Total Environ. 2018, 627, 1242-1252. [CrossRef]

34. Hoch, G.; Siegwolf, R.T.; Keel, S.G.; Körner, C.; Han, Q. Fruit production in three masting tree species does not rely on stored carbon reserves. Oecologia 2013, 171, 653-662. [CrossRef] [PubMed]

35. Streit, K.; Rinne, K.T.; Hagedorn, F.; Dawes, M.A.; Saurer, M.; Hoch, G.; Werner, R.A.; Buchmann, N.; Siegwolf, R.T. Tracing fresh assimilates through Larix decidua exposed to elevated $\mathrm{CO}_{2}$ and soil warming at the alpine treeline using compound-specific stable isotope analysis. New Phytol. 2013, 197, 838-849. [CrossRef]

36. Volpe, G.; Lo Bianco, R.; Rieger, M. Carbon autonomy of peach shoots determined by ${ }^{13}$ C-photoassimilate transport. Tree Physiol. 2008, 28, 1805-1812. [CrossRef]

37. Zhang, C.; Tanabe, K. Partitioning of ${ }^{13} \mathrm{C}$-photosynthates from different current shoots neighboring with fruiting spur in later-maturing Japanese pear during the period of rapid fruit growth. Sci. Hortic. 2008, 117, 142-150. [CrossRef]

38. Sha, J.; Wang, F.; Xu, X.; Chen, Q.; Zhu, Z.; Jiang, Y.; and Ge, S. Studies on the translocation characteristics of ${ }^{13}$ C-photoassimilates to fruit during the fruit development stage in 'Fuji'apple. Plant Physiol. Biochem. 2020, 154, 636-645. [CrossRef]

39. Desalme, D.; Priault, P.; Gerant, D.; Dannoura, M.; Maillard, P.; Plain, C.; Epron, D. Seasonal variations drive short-term dynamics and partitioning of recently assimilated carbon in the foliage of adult beech and pine. New Phytol. 2017, 213, 140-153. [CrossRef]

40. Yin, D.; Wu, H.; Zhang, J.; Ge, W.; Zhou, Z.; Shen, H. Effects of girdling and defoliation on the growth of female cones and branches and nutrient content in different tissues and organs of Pinus koraiensis. Chin. J. Appl. Ecol. 2019, 30, 3671-3680. [CrossRef]

41. Wu, H.; Yin, D.; Rodríguez-Calcerrada, J.; Zhang, J.; Gil, L.; Zhang, P.; Shen, H. Cone-bearing effects on photosynthetic traits do not change with needle age in Pinus koraiensis trees. New Forests. 2021, 1-20. [CrossRef]

42. Xu, D.; Yan, H. A study of the impacts of climate change on the geographic distribution of Pinus koraiensis in China. Environ. Int. 2001, 27, 201-205. [CrossRef]

43. Nergiz, C.; Dönmez, I. Chemical composition and nutritive value of Pinus pinea L. seeds. Food Chem. 2004, 86, 365-368. [CrossRef]

44. Mei, L.; Xiong, Y.; Gu, J.; Wang, Z.; Guo, D. Whole-tree dynamics of non-structural carbohydrate and nitrogen pools across different seasons and in response to girdling in two temperate trees. Oecologia 2015, 177, 333-344. [CrossRef]

45. Zhang, K.; Li, Z.; Li, Y.; Li, Y.; Kong, D.; Wu, R. Carbohydrate accumulation may be the proximate trigger of anthocyanin biosynthesis under autumn conditions in Begonia semperflorens. Plant Biol (Stuttg.) 2013, 15, 991-1000. [CrossRef] [PubMed]

46. Miyazaki, Y.; Hiura, T.; Funada, R. Allocation of photo-assimilated ${ }^{13} \mathrm{C}$ from reproductive and non-reproductive shoots to fruits in Styrax obassia. Plant Species Biol. 2007, 22, 53-57. [CrossRef]

47. Salomon, R.L.; De Roo, L.; Bode, S.; Boeckx, P.; Steppe, K. Efflux and assimilation of xylem-transported $\mathrm{CO}_{2}$ in stems and leaves of tree species with different wood anatomy. Plant Cell Environ. 2021. [CrossRef] [PubMed]

48. Kidombo, S.D.; Dean, T.J. Growth response of branches to variation in the intra-and interbranch supply of photosynthate. Trees 2018, 32, 1291-1300. [CrossRef]

49. Hoch, G.; Keel, S.G. ${ }^{13} \mathrm{C}$ labelling reveals different contributions of photoassimilates from infructescences for fruiting in two temperate forest tree species. Plant Biol. (Stuttg.) 2006, 8, 606-614. [CrossRef]

50. Ávila, E.; Herrera, A.; Tezara, W. Contribution of stem $\mathrm{CO}_{2}$ fixation to whole-plant carbon balance in nonsucculent species. Photosynthetica 2014, 52, 3-15. [CrossRef]

51. De Roo, L.; Salomon, R.L.; Oleksyn, J.; Steppe, K. Woody tissue photosynthesis delays drought stress in Populus tremula trees and maintains starch reserves in branch xylem tissues. New Phytol. 2020, 228, 70-81. [CrossRef]

52. Vaast, P.; Angrand, J.; Franck, N.; Dauzat, J.; Genard, M. Fruit load and branch ring-barking affect carbon allocation and photosynthesis of leaf and fruit of Coffea arabica in the field. Tree Physiol. 2005, 25, 753-760. [CrossRef]

53. Żywiec, M.; Zielonka, T. Does a heavy fruit crop reduce the tree ring increment? Results from a 12-year study in a subalpine zone. Trees 2013, 27, 1365-1373. [CrossRef]

54. Zhang, J.; Yin, D. Effects of female cone development on the vegetative growth and biomass accumulation of shoots and needles of Pinus koraiensis. Chin. J. Ecol. 2019, 38, 1646-1652. [CrossRef]

55. Han, Q.; Kabeya, D. Recent developments in understanding mast seeding in relation to dynamics of carbon and nitrogen resources in temperate trees. Environ. Res. 2017, 32, 771-778. [CrossRef]

56. Quentin, A.G.; Pinkard, E.A.; Ryan, M.G.; Tissue, D.T.; Baggett, L.S.; Adams, H.D.; Maillard, P.; Marchand, J.; Landhäusser, S.M.; Lacointe, A.; et al. Non-structural carbohydrates in woody plants compared among laboratories. Tree Physiol. 2015, 35, 1146-1165. [CrossRef] [PubMed]

57. Martínez-Vilalta, J.; Sala, A.; Asensio, D.; Galiano, L.; Hoch, G.; Palacio, S.; Piper, F.I.; Lloret, F. Dynamics of non-structural carbohydrates in terrestrial plants: A global synthesis. Ecol. Monogr. 2016, 86, 495-516. [CrossRef]

58. Mitchell, P.J.; O'Grady, A.P.; Tissue, D.T.; Worledge, D.; Pinkard, E.A. Co-ordination of growth, gas exchange and hydraulics define the carbon safety margin in tree species with contrasting drought strategies. Tree Physiol. 2014, 34, 443-458. [CrossRef]

59. Hoch, G.; Richter, A.; Körner, C. Non-structural carbon compounds in temperate forest trees. Plant Cell Environ. 2003, 26, 1067-1081. [CrossRef] 
60. Hartmann, H.; Moura, C.F.; Anderegg, W.R.; Ruehr, N.K.; Salmon, Y.; Allen, C.D.; Arndt, S.K.; Breshears, D.D.; Davi, H.; Galbraith, D.; et al. Research frontiers for improving our understanding of drought-induced tree and forest mortality. New Phytol. 2018, 218, 15-28. [CrossRef] [PubMed]

61. Epron, D.; Bahn, M.; Derrien, D.; Lattanzi, F.A.; Pumpanen, J.; Gessler, A.; Hogberg, P.; Maillard, P.; Dannoura, M.; Gérant, D.; et al. Pulse-labelling trees to study carbon allocation dynamics: A review of methods, current knowledge and future prospects. Tree Physiol. 2012, 32, 776-798. [CrossRef] [PubMed]

62. Gao, F.; Peng, C.X.; Wang, H.; Shen, H.L.; Yang, L. Selection of culture conditions for callus induction and proliferation by somatic embryogenesis of Pinus koraiensis. J. For. Res. (Harbin) 2020, 32, 483-491. [CrossRef]

63. Spann, T.M.; Beede, R.H.; DeJong, T.M. Seasonal carbohydrate storage and mobilization in bearing and non-bearing pistachio (Pistacia vera) trees. Tree Physiol. 2008, 28, 207-213. [CrossRef] [PubMed]

64. Han, Q.; Kagawa, A.; Kabeya, D.; Inagaki, Y. Reproduction-related variation in carbon allocation to woody tissues in Fagus crenata using a natural ${ }^{13} \mathrm{C}$ approach. Tree Physiol. 2016, 36, 1343-1352. [CrossRef]

65. Xie, P.; Guo, S. Patterns of photoassimilate translocation between shoots in Chinese chestnut trees during flowering and fruit growth. Aust. For. 2015, 78, 86-91. [CrossRef] 